ROCZNIKI TEOLOGICZNE

Tom LXVIII, zeszyt $1-2021$

DOI: https://doi.org/10.18290/rt21681-2

\title{
LISTY, KTÓRYCH NIE BYŁO. TEOLOGICZNA INTERPRETACJA CZASU EPIDEMII W LISTACH PASTERSKICH BISKUPÓW POLSKICH
}

\author{
THE UNWRITTEN LETTERS. \\ A THEOLOGICAL INTERPRETATION OF THE TIME OF THE EPIDEMIC \\ IN THE PASTORAL LETTERS OF POLISH BISHOPS
}

\begin{abstract}
A b stract. The documents of the post-Vaticanum II Church make it clear that preaching the word of God is a priority among bishops' duties. Besides preaching the truths of the faith, an important duty of theirs is interpreting the contemporary reality in the perspective of the Gospel. The documents on the pastoral office of bishops present a pastoral letter as a basic form of preaching, besides a homily, and specify that pastoral letters ought to be published in situations of extraordinary circumstances for the Church. Seemingly, the coronavirus epidemic causing the COVID-19 disease has been such a special situation for the Church. A search of official Internet pages of dioceses has shown that from March to the end of June 2020 among 41 diocesan bishops of the Latin rite in Poland only 12 have released letters dedicated (entirely or partially) to the issues concerning the epidemic. Only 3 of the letters presented attempts of a theological interpretation, including biblical models. Similarly, only 3 bishops have discussed the issue of interpreting the epidemic in terms of a supernatural evil. In other letters a pedagogical model of teaching prevailed. The authors wrote of the epidemic as a time of trial, a chance and opportunity to change ones ways and repent. The bishops did not take the opportunity to present a deeper theological reflection of the epidemic sub specie aeternitatis.
\end{abstract}

Key words: pastoral letter; bishop; coronavirus epidemic; evil.

Wśród pasterskich funkcji powierzonych biskupom Sobór Watykański II na pierwsze miejsce wysunął nauczanie. W soborowym Dekrecie Christus Dominus czytamy, że głoszenie Ewangelii „wysuwa się na czoło wśród zasadniczych

Ks. dr hab. ANDRZej DraguŁA, prof. US - Katedra Teologii Praktycznej, Wydział Teologiczny, Uniwersytet Szczeciński; adres do korespondencji: ul. Pawła VI 2, 71-459 Szczecin; e-mail: andrzej.dragula@usz.edu.pl; ORCID: https://orcid.org/0000-0002-3287-3119. 
zadań biskupich"1. Dyspozycja soborowa znalazła swoje potwierdzenie w Adhortacji posynodalnej Pastores gregis, w której papież Jan Paweł II przypomina:

Jeśli obowiązek głoszenia Ewangelii leży w naturze całego Kościoła i każdego z jego synów, ma to miejsce szczególnie w przypadku biskupów, którzy w dniu święceń włączających ich w sukcesję apostolską, przyjmują jako główny obowiązek głoszenie Ewangelii. [...] głoszenie Chrystusa stoi zawsze na pierwszym miejscu, biskup zaś jest pierwszym głosicielem Ewangelii słowem i świadectwem własnego życia²

\section{PROROCKA FUNKCJA BISKUPÓW}

Jeśli chodzi o przedmiot biskupiego przepowiadania, to czymś pierwszoplanowym jest oczywiście przepowiadanie prawd wiary i całości tajemnicy Chrystusowej, ale Sobór Watykański II wskazuje także na jeszcze inny zakres przedmiotowy przepowiadania. Zachęca bowiem biskupów: „niech wykazują, że nawet rzeczy doczesne oraz instytucje ludzkie kierowane są również wedle zamiarów Boga Stwórcy ku zbawieniu ludzi"3. W ten sposób sobór podkreśla prorocki wymiar posługi słowa, który to wymiar polega na przepowiadaniu interpretatywnym, a więc takim, gdzie głoszone prawdy wiary korelują z interpretowanym doświadczeniem. „Dlatego - wzywa dalej sobór - niech pouczają, jak należy oceniać w myśl nauki Kościoła osobę ludzką razem z jej wolnością i z samym życiem ciała; rodzinę oraz jej jedność i stałość, wydawanie i wychowanie potomstwa; społeczność świecką z jej prawami i stanami; pracę i wypoczynek, wiedzę i wynalazki techniczne; nędzę i nadmiar dóbr"4. Szczegółowe określenie zagadnień, które powinny być podejmowane w nauczaniu biskupów, pojawiło się następnie w kolejnych dokumentach Kongregacji ds. Biskupów ${ }^{5}$, a także w Adhortacji apostolskiej Pastor gregis Jana Pawła II z roku 1988.

Szczególne znaczenie ma według papieża głoszenie orędzia nadziei: „Zadaniem każdego biskupa jest w rzeczywistości głoszenie światu nadziei, poczynając od głoszenia Ewangelii Jezusa Chrystusa: nadziei nie tylko w odniesieniu do rzeczy przemijających, lecz także i przede wszystkim nadziei eschatologicznej”. Wielokrotnie w dokumencie powraca myśl, że biskup powinien być prorokiem

\footnotetext{
${ }^{1}$ SOBÓR WATYKAŃSKi II, Dekret o pasterskich zadaniach biskupów „, Christus Dominus”, nr 12 (dalej cyt. ChD); zob. TeNŻE, Konstytucja dogmatyczna o Kościele „,Lumen gentium”, nr 7, 23, 25, 27, 32.

2 JAN PAWE⿺ II, Adhortacja posynodalna „Pastores gregis”, nr 26 (dalej cyt. PG).

${ }^{3} \mathrm{ChD} 12$.

${ }^{4}$ Tamże.

${ }^{5}$ Zob. KONGREGACJA DS. BISKUPÓw, Instrukcja na temat pasterskiej postugi biskupów „Ecclesiae imago", nr 56 (dalej cyt. EI); KONGREGACJA DS. BISKUPÓw, Dyrektorium o pasterskiej postudze biskupów „Apostolorum succesores”, nr 120 (dalej cyt. AS).
} 
nadziei wobec sytuacji, w których dominuje zło, cierpienie, śmierć czy niesprawiedliwość. Biskup ,powinien być świadom wyzwań, jakie niosą dzisiejsze

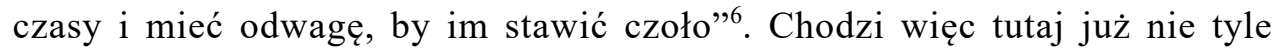
o przekaz prawd wiary, co o interpretację rzeczywistości w świetle wiary, a więc odczytywanie rzeczywistości w optyce „znaków czasu” (signa temporis).

W soborowej Konstytucji duszpasterskiej o Kościele w świecie współczesnym Gaudium et spes czytamy: „Kościół zawsze ma obowiązek badać znaki czasów i wyjaśniać je w świetle Ewangelii, tak aby mógł w sposób dostosowany do mentalności każdego pokolenia odpowiadać ludziom na ich odwieczne pytania dotyczące sensu życia obecnego i przyszłego oraz wzajemnego ich stosunku do siebie. Należy zatem poznawać i rozumieć świat, w którym żyjemy, a także jego nieraz dramatyczne oczekiwania, dążenia, właściwości"7. Za „znaki czasu” należy więc uznać wszystkie wydarzenia, potrzeby, pragnienia, zjawiska, które poprzez swoją powszechność dotykają cały świat, a w których „Lud Boży [...] uczestniczy z resztą ludzi naszej doby”.

„Znaki czasu” - jak pisał Apoloniusz Żynel - „to zjawiska, które przez swoją ogólność i częste występowanie charakteryzują daną epokę" ". Sobór każe tak analizować „znaki czasów”, aby „rozpoznać, jakie w nich mieszczą się prawdziwe znaki obecności lub zamysłów Bożych" ${ }^{10}$. Chodzi więc tutaj o teologiczną interpretację głosów współczesnego świata, której należy dokonywać w świetle Ewangelii, wiary bądź słowa Bożego ${ }^{11}$. Tak ujęta koncepcja „znaków czasu” pozwala dostrzegać dziejącą się historię ludzką jako przestrzeń dokonującej się wciąż Bożej ekonomii zbawienia. Ta kairologiczna optyka pozwala rozumieć każdy historyczny moment jako wyzwanie.

Wydaje się czymś oczywistym, że epidemia koronawirusa, która pojawiła się w Polsce w pierwszych dniach marca 2020 r., stanowi nie tylko wyzwanie natury medycznej, epidemiologicznej, sanitarnej czy organizacyjnej, ale jest także wyzwaniem natury teologicznej i spełnia wszystkie kryteria „znaków czasu". Pytano o medyczne przyczyny rozprzestrzeniania się nowej epidemii, prognozy jej rozwoju czy też leczenia, ale także o jej sens nadprzyrodzony, o jej znaczenie sub specie aeternitatis. Powszechne zagrożenie chorobą i śmiercią prowokowało do postawienia na nowo starego pytania teodycei: unde malum? Czy epidemia jest karą od Boga, czy też może w ogóle nie należy w niej się

\footnotetext{
${ }^{6} \mathrm{PG} 26$.

${ }^{7}$ SOBÓR WATYKAŃSKI II, Konstytucja duszpasterska o Kościele w świecie wspótczesnym „, Gaudium et spes”, nr 4 (dalej cyt. KDK).

${ }^{8}$ Tamże, s. 11.

${ }^{9}$ A. ŻYNel, Znaki czasu, „Znak” (1969) nr 12, s. 1587.

${ }^{10} \mathrm{KDK} 11$.

${ }^{11} \mathrm{KDK} 4,11,44$.
} 
doszukiwać nadprzyrodzonej genezy? Jest dopustem czy może czasem łaski danym nam od Boga? Naturalnymi adresatami tych pytań stali się księża, ale byli nimi także biskupi jako nauczyciele wiary, od których oczekuje się interpretatywnego głoszenia Ewangelii.

\section{EPIDEMIA JAKO WYZWANIE TEOLOGICZNE}

Podstawową formą biskupiego przepowiadania jest homilia ${ }^{12}$. W czasie pandemii przepowiadanie homilijne nabrało nowego wymiaru, ponieważ dzięki transmisjom Mszy świętych to właśnie za pośrednictwem homilii biskup mógł docierać do szerokiego grona swoich diecezjan. Przedmiotem niniejszej analizy nie będą jednak homilie, ale listy pasterskie, które w Polsce są rozpowszechnioną i uznaną formę urzędowego nauczania biskupa ${ }^{13}$. Trzeba nadmienić, że list pasterski, obok homilii, stanowi formę przepowiadania zalecaną przez dokumenty kościelne. I tak, instrukcja Ecclesiae imago udziela wskazań, aby bardziej przystosować tę formę nauczania do współczesnych potrzeb. Listy biskupów powinny być krótsze, ale za to częściej wydawane, aby biskup nie milczał wtedy, gdy okoliczności domagają się jego głosu ${ }^{14}$.

Rola listów pasterskich została potwierdzona w Dyrektorium Apostolorum successores z roku 2004. Dokument przypomina raz jeszcze, że drugą - obok homilii - formą pasterskiego przepowiadania są listy pasterskie oraz przesłania wydawane „przy okazji szczególnych okoliczności życia diecezjalnego" ${ }^{15}$. Dyrektorium wskazuje, że listy powinny być odczytywane we wszystkich kościołach i oratoriach, a także rozpowszechniane jak najszerzej wśród wiernych jako teksty drukowane ${ }^{16}$. Dodajmy, że współcześnie mogą one być także publikowane w środkach masowego komunikowania, w tym w Internecie,

12 EI 59, PG 26; K. Drews, Posługa biskupa we współczesnym Kościele, „Studia Gdańskie” 25(2009), s. 41.

13 „List pasterski jest tekstem epistolarnym, użytkowym, oficjalnym. Różni się od innych listów oficjalnych charakterystycznymi uwarunkowaniami pragmatycznymi, przede wszystkim szczególnym statusem nadawcy i wynikającą z niego asymetrycznością przekazu [...]. Definiuje się go jako gatunek wtórny wobec listu (prywatnego), spokrewniony z innymi gatunkami, takimi jak: kazanie, dokument o funkcji regulatywnej (np. instrukcja), traktat teologiczny, odezwa”. K. SKOwRONEK, Między sacrum a profanum. Studium językoznawcze listów pasterskich Konferencji Episkopatu Polski (1945-2005), Wydawnictwo Lexis, Kraków 2006, s. 53; por. M. WoJTAK, List pasterski pragmatyczny aspekt wzorca gatunkowego, w: red. J. Gardzińska, A. Maciejewska, Znak językowy w pejzaży semiotycznym. Księga pamiatkowa ku czci Profesora Józefa Wierzchowskiego, Wydawnictwo Akademii Podlaskiej, Siedlce 2003, s. 185-198.

${ }^{14}$ EI 64; por. K. DREWS, Postuga biskupa, s. 42.

${ }^{15} \mathrm{AS}, \mathrm{nr} 122 \mathrm{~b}$.

${ }^{16}$ Tamże. 
gdzie każda diecezja dysponuje swoją stroną internetową czy profilem w mediach społecznościowych.

Wydawać by się mogło, że sytuacja epidemii jest okolicznością, która powinna sprowokować do wydania okolicznościowego listu pasterskiego. Okazuje się jednak, że w tym czasie biskupi polscy powszechnie wydawali dekrety, rozporządzenia, publikowali komunikaty i okolicznościowe słowa, które skupiały się przede wszystkim na kwestiach organizacyjnych, kanonicznych czy duszpasterskich. Rzadko biskupi ujawniali w swoich wypowiedziach potrzebę przejścia $\mathrm{z}$ poziomu organizacyjnego na teologiczno-duchowy. Tylko w dwóch przypadkach biskupi wyrazili wprost taką potrzebę. Arcybiskup Józef Kupny pisał do mieszkańców Dolnego Śląska: „W związku z obecną sytuacją wydałem wiele dekretów dotyczących naszego życia religijnego. Nie chcę jednak, by nasza łączność pozostawała jedynie na poziomie prawnych uregulowań" ${ }^{17}$. Podobną deklarację złożył arcybiskup Grzegorz Ryś z Łodzi: „Wiecie dobrze, że w związku z rozszerzającą się pandemią koronawirusa wydałem szereg zarządzeń dotyczących naszego życia religijnego w najbliższych tygodniach. Nie chcę jednak poprzestać na przypomnieniu czy sformułowaniu jedynie prawnych regulacji. Chcę się także podzielić z Wami najważniejszymi myślami, które je uzasadniają"18.

Kwerenda przeprowadzona na stronach internetowych 41 diecezji obrządku łacińskiego w Polsce pozwoliła na wyodrębnienie jedynie 13 listów pasterskich wydanych w okresie od marca do końca czerwca 2020 r. - a więc do momentu powszechnego odwołania dyspens od obowiązku udziału w niedzielnej Mszy świętej - które zostały w całości bądź przynajmniej częściowo poświęcone kwestiom związanym z epidemią koronawirusa. Wzięto pod uwagę wyłącznie te wypowiedzi, które utrzymują się w ramach gatunku listu pasterskiego, z pominięciem form o charakterze regulacyjnym. Jako jeden $\mathrm{z}$ istotnych wyznaczników przyjęto formę drukowaną, publikowaną jako pierwotną, przeznaczoną do odczytania. W jednym przypadku (list, którego autorem jest bp Roman Pindel) analizowany tekst ma jedynie formę mówioną (czytaną) przez samego autora, przy zachowaniu innych wyznaczników gatunku, takich jak struktura, treść oraz odautorskie określenie wypowiedzi jako listu. W jednym też przypadku (list abp. Grzegorza Rysia) list pasterski opublikowano jednocześnie w dwóch formach: drukowanej oraz czytanej przez autora tekstu.

${ }^{17}$ J. KuPNY, List Metropolity Wrocławskiego ks. abp. Józefa Kupnego do wiernych Archidiecezji Wroctawskiej, 19.03.2020 r., www.archidiecezja.wroc.pl/index.php?option=com_content\&view=article \&id=2814:kochani-mieszkacy-dolnego-lska\&catid=62:aktualnoci\&Itemid=205 (dostęp: 28.06.2020)

${ }^{18}$ G. RYŚ, List do diecezjan dotyczacy pandemii koronawirusa, 14.03.2020 r., www.archidiecezja. lodz.pl/film/abp-rys-list-do-diecezjan-dot-pandemii-koronawirusa-lodz-2020/ (dostęp: 28.06.2020). 
Listy pasterskie spełniające przyjęte kryteria formalne i treściowe wydało jedynie 13 biskupów diecezjalnych ${ }^{19}$ : bp Andrzej Czaja (diecezja opolska), abp Andrzej Dzięga (archidiecezja szczecińsko-kamieńska), bp Kazimierz Gurda (diecezja siedlecka), bp Andrzej Jeż (diecezja tarnowska), abp Marek Jędraszewski (archidiecezja krakowska), bp Grzegorz Kaszak (diecezja sosnowiecka), abp Józef Kupny (archidiecezja wrocławska), bp Roman Pindel (diecezja bielsko-żywiecka), abp Wojciech Polak (archidiecezja gnieźnieńska), abp Grzegorz Ryś (archidiecezja łódzka), bp Piotr Sawczuk (diecezja drohiczyńska), bp Janusz Stepnowski - 2 listy (diecezja łomżyńska) oraz bp Wiesław Śmigiel (diecezja toruńska). Korpus obejmujący 14 tekstów jest podstawą prezentowanej analizy.

\section{ANALOGIE TEOLOGICZNE}

Tylko trzech biskupów zaproponowało w swoich listach teologiczne analogie między czasem epidemii a sytuacjami wiary opisywanymi w Biblii, które były traktowane jako matryce interpretacyjne. Dwóch odwołało się do czytań liturgicznych przewidzianych na daną niedzielę, trzeci natomiast nawiązał do arbitralnie wybranej perykopy ze Starego Testamentu.

Bp Jeż z diecezji tarnowskiej w liście wydanym na Niedzielę Miłosierdzia Bożego przyrównywał wynikającą $\mathrm{z}$ zalecenia do pozostania $\mathrm{w}$ domu sytuację wiernych do położenia uczniów po śmierci Jezusa ${ }^{20}$ :

Przebywali oni zgromadzeni w Wieczerniku, którego drzwi były zamknięte, żywiąc w swych sercach tak wiele obaw i niepokoju o przyszłość. Podobny ciężar uczuć przygniata nas od kilku tygodni. Przymuszeni panującą sytuacją, trwamy zamknięci w murach naszych domów i mieszkań, które stały się też zarazem swoistymi „wieczernikami" domowego Kościoła.

Autor listu nie zatrzymuje się jednak wyłącznie na analogii dotyczącej sytuacji zagrożenia, ale pokazuje także podobieństwo sytuacji wyzwolenia ze stanu niepewności, zamknięcia, zagrożenia złem: „W tych dniach pełnych

${ }^{19} \mathrm{~W}$ zapisie bibliograficznym zachowano oryginalne tytuły listów, którymi zostały one opatrzone przez ich autorów bądź administratorów strony. Jeśli nie podano daty podpisania listu, przyjęto datowanie właściwe dla dnia publikacji na stronie diecezjalnej.

${ }^{20} \mathrm{Na}$ II Niedzielę Wielkanocną, Święto Miłosierdzia Bożego, przewidziana jest Ewangelia J 20, 19-31, która rozpoczyna się od słów: „Wieczorem w dniu zmartwychwstania, tam gdzie przebywali uczniowie, choć drzwi były zamknięte z obawy przed Żydami, przyszedł Jezus, stanął pośrodku i rzekł do nich: «Pokój wam!»”. 
niepewności staje pośród nas Zmartwychwstały Chrystus i jak niegdyś zalęknionym uczniom, zamkniętym w murach Wieczernika, przynosi dar Bożego pokoju, jakiego świat dać nie potrafi" ${ }^{21}$.

Najbardziej rozbudowaną analogię do sytuacji biblijnej zastosował w swoim liście na V Niedzielę Wielkiego Postu bp Czaja z Opola. Punktem wyjścia stała się dla niego Ewangelia o wskrzeszeniu Łazarza, przeznaczona na tę niedzielę (J 11, 1-45). Biskup wskazuje na ważny aspekt postępowania Jezusa: „Pan Jezus mógł zdążyć na czas, gdyby chciał. Wyraźnie się jednak ociągał. [...] Wyruszył w drogę dopiero wtedy, gdy już wiedział, że Łazarz umarł". W tym postępowaniu ukryta była pedagogika Jezusa, który chciał, aby cud wskrzeszenia stał się dla Jego uczniów źródłem wiary. Wychodząc z tego założenia, bp Czaja interpretuje postawę Boga w czasie obecnej epidemii. Po pierwsze, „Pan Bóg jest $\mathrm{z}$ nami i w tej bardzo trudnej dla nas sytuacji możemy domniemywać, że boleje razem z nami, tak, jak wówczas przy grobie Lazarza, gdy wzruszył się i rozrzewnił na widok płaczącej Marii i zgromadzonych Żydów”. Po wtóre, te „obecne chwile niepewności i strapienia są powiązane z określonym zamysłem Boga, który z czasem stanie się dla nas jeszcze bardziej czytelny". Biskup dopowiada także, co mogło być tym zamysłem Boga: „To bowiem, że w tych dniach więcej się modlimy i że wielu z nas zbliżyło się do Jezusa, jest już niezaprzeczalnym faktem". Bp Czaja reinterpretuje także dialog między Jezusem a Martą. Słowa św. Marty skierowane do Jezusa: „ "Lecz i teraz wiem, że Bóg da Ci wszystko, o cokolwiek byś prosił Boga», niech nas ośmielają i mobilizują do ciągłego i ufnego wołania o łaskę opanowania pandemii i ocalenia ludzkości od pomoru". Autor listu przesuwa jednak interpretacyjny punkt ciężkości z modlitwy o ustanie epidemii w kierunku postawy zaufania. Według niego „najważniejsze w przygotowaniu się na Święta Wielkanocne, niezależnie od sytuacji i uwarunkowań naszego życia”, jest, aby „w tych dniach obudzić, umocnić i rozwijać swoją wiarę"22.

Bp Kaszak zbudował analogię między sytuacją epidemii a wydarzeniem biblijnym na zasadzie podobieństwa rzeczowego. Autor nawiązuje do wydarzeń opisanych w Drugiej Księdze Samuela (2 Sm 24), gdy - jak relacjonuje biskup - ,przez grzech człowieka na naród wybrany przyszła zaraza, która zebrała obfite żniwo śmierci". Przypomnijmy, że chodzi tutaj o karę, którą wybrał sam król Dawid jako konsekwencję dokonanego spisu ludności. Czyn ten został

${ }^{21}$ A. JEŻ, List pasterski Biskupa Tarnowskiego na Niedzielę Bożego Miłosierdzia, 19.04.2020 r., diecezja.tarnow.pl/images/do_pobrania/List_NMB_2020.pdf (dostęp: 28.06.2020).

22 A. Czaja, List Biskupa Opolskiego na V niedzielę Wielkiego Postu 2020 „Jeśli uwierzysz, ujrzysz chwate Boża”, 29.03.2020 r., www.diecezja.opole.pl/index.php/biskupi-informacje/bp-andrzejczaja/2525-list-bisku pa-opolskiego-na-v-niedziele-wielkiego-postu-2020 (dostęp: 28.06.2020). 
odebrany przez Boga jako wkroczenie w Jego własne kompetencje, dlatego „zesłał [...] Pan na Izraela zarazę od rana do ustalonego czasu” (2 Sm 24, 15). Gdy anioł wyciągał już rękę nad Jerozolimą, Pan jednak ulitował się nad Izraelem i epidemia ustała.

W interpretacji bp. Kaszaka nie pojawia się wprost odpowiedź na pytanie o nadprzyrodzoną genezę współczesnej epidemii, a Bóg jest nie tyle tym, który ją zsyła, co tym, który ją może oddalić czy pokonać. O ile bowiem w przypadku sytuacji biblijnej podkreślony został związek między grzechem a epidemią jako karą, o tyle odnosząc się do współczesności, takiego związ$\mathrm{ku}$ autor listu już nie sugeruje, zrywając tym samym genetyczny związek między zarazą a Bogiem. Według niego to „od Boga pochodzi moc, która jest zdolna pokonać każde zło"23.

\section{EPIDEMIA JAKO KARA}

Nie ulega wątpliwości, że na płaszczyźnie naturalnej epidemia koronawirusa jest złem. Człowiek wierzący pyta jednak także o nadprzyrodzoną interpretację wydarzeń. W dyskursie publicystycznym pojawiły się głosy jednoznacznie wskazujące, że epidemia koronawirusa jest zesłaną przez Boga karą za grzechy. Podawano także listę owych wykroczeń przeciwko Bogu ${ }^{24}$. W listach pasterskich polskich biskupów pojawiły się tylko pojedyncze, i to raczej akcydentalne nawiązania do powyżej kwestii, a żaden z biskupów nie uczynił tego problemu głównym tematem swojego listu.

W Liście na III Niedzielę Wielkiego Postu abp Dzięga przestrzegał: „Nie należy dzisiaj pytać, kto zgrzeszył, że pandemia się rozwija. Może być bowiem i tak, że Bóg chce nam dać Znak nowej Mocy i nowego Życia, jeśli tylko my damy świadectwo naszego zawierzenia" ${ }^{25}$. Nie znaczy to jednak, że kontekst grzechu zupełnie nie pojawia się w liście. W następnych zdaniach bowiem czytamy: „Ale mamy też świadomość poważnych grzechów. To są grzechy

\footnotetext{
${ }^{23}$ G. KASZAK, List biskupa Grzegorza Kaszaka w zwiazku z epidemia, 15.03 .2020 r., diecezja. sosnowiec.pl/news/list-biskupa-w-zwiazku-z-epidemia-3881 (dostęp: 28.06.2020).

${ }^{24}$ Szczególne znaczenie miało tutaj nagranie wideo: L. DoKOwicz, M. BodAsińsKi, Wezwanie do pokuty, 9.03.2020 r., www.youtube.com/watch? $\mathrm{v}=\mathrm{zNsLJ}$ r0dqOk (dostęp: 30.06.2020). Krytycznie odpowiedział na nie: P. SAWA, Projekt Ocalenie - czyli jakie błędy popetniaja Bodasiński $i$ Dokowicz, deon.pl/kosciol/komentarze/jakie-bledy-popelniaja-bodasinski-i-dokowicz-, 834302 (dostęp: 30.06.2020).

${ }^{25}$ Jest to wyraźna aluzja do sceny ewangelicznej: „Jezus przechodząc obok ujrzał pewnego człowieka, niewidomego od urodzenia. Uczniowie Jego zadali Mu pytanie: «Rabbi, kto zgrzeszył, że się urodził niewidomym - on czy jego rodzice?»" (J 9, 1-2).
} 
nasze - osobiste, i nasze - polskie, i nasze - europejskie, i nasze - światowe. Wszyscy winniśmy zwrócić się na nowo do Boga. Nie lękajcie się więc, tylko zachowajcie wiarę". Wprowadzenie kategorii grzechu bezpośrednio po stwierdzeniu, iż „nie należy pytać, kto zgrzeszył”, nieco mąci klarowność wywodu. $\mathrm{Z}$ jednej bowiem strony autor listu sugeruje, że epidemia nie jest karą za grzech, z drugiej jednak mówi o konieczności nawrócenia, co może sugerować rozumienie epidemii jako kary. Wątek ten abp Dzięga kończy tezą o absolutnej supremacji Boga nad złem: „A przecież Bóg jest ponad wirusem”26.

W sposób podobnie niejednoznaczny o związku między epidemią a karą pisze bp Kaszak. W zakończeniu listu - choć jedynie implicite - pojawia się bowiem wątek zarazy jako ewentualnej kary za grzechy. Biskup wzywa: „I nie obrażajmy już więcej dobrego Boga, aby nasze modlitwy i wyrzeczenia były Mu miłe i sprowadziły na Polskę i cały świat zdrowie i szczęście"27. Logicznie rzecz biorąc, należy więc założyć, że skoro modlitwy i wyrzeczenia sprowadzają zdrowie i szczęście, to choroba i nieszczęście są skutkiem „obrażania dobrego Boga”, którego nie należy ,już więcej” obrażać.

W wyraźnym tonie polemicznym wobec koncepcji utożsamienia epidemii z karą zesłaną przez Boga utrzymana jest wypowiedź abp. Rysia:

Pan nie przychodzi do nas jako epidemia. Pandemia nie jest twarzą Boga! JEGO TWARZĄ JEST MIŁOŚĆ - także ta, która w nas z nową mocą się rodzi w chwilach takich wyzwań: miłość, solidarność, sąsiedzka pomoc, wzajemna modlitwa za siebie. BÓG NIE MA INNEJ TWARZY NIŻ MIŁOŚĆ I MIŁOSIERDZIE. Każdy inny Jego portret - niezależnie od tego, kto go maluje - jest karykaturą $[\ldots]^{28}$.

Czynienie z Boga podmiotu bezpośrednio zsyłającego epidemię jako karę za grzech jest według autora listu niezgodne z poprawnym obrazem Boga chrześcijan.

${ }^{26}$ A. DZIĘGA, Stowo pasterskie Księdza Arcybiskupa Metropolity na III Niedzielę Wielkiego Postu, 15.03.2020 r., kuria.pl/aktualnosci/Slowo-pasterskie-Ksiedza-Arcybiskupa-Metropolity-na-IIINiedziele-Wielkiego-Postu-15-marca-2020-r_4008 (dostęp: 28.06.2020).

${ }^{27}$ G. KASZAK, List biskupa Grzegorza Kaszaka w związu z epidemia.

${ }^{28}$ G. RYŚ, List do diecezjan dotyczacy pandemii koronawirusa (wyróżnienia w tekście wersalikami odzwierciedlają oryginalny zapis dokumentu). Dla uzupełnienia należy dodać, że podobne słowa padły także w orędziu abp. W. Polaka: „Nie bójmy się. Jesteśmy w rękach Boga. On nie zostawia nas samych w momentach doświadczenia, choroby czy cierpienia. Pan nie przychodzi do nas jako epidemia. Pandemia nie jest karą zesłaną na nas przez Pana Boga. On jest miłością. Także tą, która w takich właśnie chwilach rodzi w nas, z takich trudnych wyzwań, miłość, sąsiedzką pomoc, solidarność, ale też odpowiedzialność i wzajemną modlitwę za siebie i modlitwę, gorącą modlitwę o ustanie epidemii”. W. PoLAK, Jesteśmy w rękach Boga, 17.03.2020 r., www.archidiecezja.pl/ aktualnosci/archiwum/2020/marzec/jestesmy_w_rekach_boga_html (dostęp: 30.06.2020). 


\section{EPIDEMIA JAKO CZAS NAWRÓCENIA I POKUTY}

Kategoria grzechu łączy się bezpośrednio z wezwaniem do pokuty i nawrócenia, a także $\mathrm{z}$ tajemnicą miłosierdzia, które jest ostateczną odpowiedzią Boga na grzech. Właśnie w kontekście tajemnicy Bożego Miłosierdzia interpretował epidemię w swoim rozbudowanym liście bp Jeż. Nawiązując do cytatu ze św. Faustyny, która zapisała w swoim „Dzienniczku” słowa Jezusa: „[...] nie masz nędzy, która by mogła się mierzyć z miłosierdziem moim”, biskup stwierdził: „Pandemia to nędza, która nas obecnie dotyka. Bądźmy jednak pewni, że ani ona, ani też żadna inna ludzka nędza nie mogą się mierzyć z mocą Boga bogatego w miłosierdzie, który sam troszczy się o wszystkich, którzy Mu ufają".

Trudno jednoznacznie przesądzić, w jaki sposób autor rozumie utożsamienie epidemii z nędzą. Internetowy słownik języka polskiego notuje dwa znaczenia słowa „nędza”. Pierwsze to „bieda, ubóstwo, niedostatek, brak środków do życia”; drugie znaczenie - opatrzone kwantyfikatorem „dawniej” - to „niedola, nieszczęście”"29. Zważywszy, że bp Jeż nawiązuje tutaj bezpośrednio do św. Faustyny, chodziłoby raczej o to drugie, bardziej archaiczne znaczenie. Epidemia to nędza w znaczeniu „ludzka niedola”, „stan nieszczęścia”, na które zaradzić może jedynie Boże Miłosierdzie.

Nie ma tutaj bezpośredniego odwołania się do stanu grzechu, ale ciąg dalszy listu wprowadza kategorię nawrócenia, które odwołuje się przecież do stanu grzechu. Biskup stwierdza: „Ogólnoświatowy kryzys spowodowany pandemią koronawirusa pośrednio przypomina o istniejącym równolegle o wiele poważniejszym kryzysie duchowym i moralnym, jaki od lat trawi współczesną ludzkość”. Wyrażenie „kryzys moralny” można tutaj zinterpretować jako synonim grzechu. Nie dziwi więc ciąg dalszy listu: „Dlatego też przesłanie o Bożym Miłosierdziu, które prowadzi do wydobycia człowieka z nędzy, odczytujemy przede wszystkim jako wezwanie i okazję do dogłębnego nawrócenia" ${ }^{30}$. Pandemia nie jest karą za grzechy, ale to nie zwalnia nas z nawrócenia - można by skonkludować myśl autora.

Analogia między epidemią a grzechem pojawia się także w liście pasterskim abp. Jędraszewskiego. Analogia ta jest nie tyle kanwą rozważań, co stanowi pewną ramę retoryczną listu, ponieważ pojawia się wyłącznie na wstępie listu i w jego zakończeniu. W incipicie czytamy: „Wielki Post w roku 2020 ma niezwykły charakter. Walce z grzechem, która toczy się w ludzkich

\footnotetext{
${ }^{29}$ Por. Nędza, sjp.pl/nędza (dostęp: 29.06.2020).

${ }^{30}$ A. JEŻ, List pasterski Biskupa Tarnowskiego na Niedzielę Bożego Miłosierdzia.
} 
sercach, towarzyszy walka z pandemią na wielu odcinkach życia. Rośnie intensywność jednej i drugiej walki. Potrzebna jest coraz większa mobilizacja $\mathrm{w}$ pokonaniu wirusa, ale nie mniejsza musi być determinacja w odrzuceniu grzechu”. Z kolei w zakończeniu arcybiskup Jędraszewski błogosławi „na wszystkie przeżycia, a szczególnie na podwójną walkę, jaką przeżywamy, czyli walkę z grzechem i walkę z koronawirusem"31. Autor listu nie sugeruje więc istnienia bezpośredniego, genetycznego związku między wirusem a grzechem, są to raczej dla niego rzeczywistości równoległe, a może nawet wzajemnie się reprezentujące, niejako odbijające się w sobie.

\section{EPIDEMIA JAKO PRÓBA}

Słowo „próba” wydaje się jednym z najszybciej narzucających się terminów interpretacyjnych. Jest to zarazem termin najbardziej neutralny, sytuujący się między rozumieniem analizowanej sytuacji jako szansy lub zagrożenia. Nie dziwi więc, że kategoria próby cieszy się dużą popularnością wśród polskich biskupów i pojawia się w wielu listach pasterskich.

W liście na Wielki Czwartek bp Sawczuk wyjaśnia przyczynę nieobecności kapłanów w katedrze oraz wielkoczwartkowej Mszy bez ludu: „panuje w świecie groźna epidemia i owładnął nami strach”. Biskup pisze wprost: „Musimy przetrwać tę próbę”, a następnie wzywa „do przyjęcia trudnego doświadczenia"32.

Podobny $\mathrm{w}$ tonie jest list bp. Stepnowskiego wydany $\mathrm{z}$ okazji pieszej pielgrzymki na Jasną Górę. Biskup pisze o „trudnościach i nowych wyzwaniach" w życiu społecznym, ekonomicznym, religijnym. Stawia pytanie o właściwą reakcję ludzi wierzących, gdy „ludzkie zabezpieczenia” okazały się słabe. Odpowiedzi jednak nie rozwija, ograniczając się do bardzo ogólnego stwierdzenia, iż źródłem nadziei i siły dla każdego jest Bóg i Jego bezwarunkowa miłość ujawniająca się w Jezusie Chrystusie ${ }^{33}$. We wcześniejszym liście pasterskim z dnia 13 marca 2020 r. bp Stepnowski określił czas epidemii jako „szczególne rekolekcje dla całego Kościoła” i czas „trudnych wyzwań”, a także nazwał go „szczególnym momentem próby dla osób

${ }^{31}$ M. JĘDRASZEWSKI, List ze wskazaniami duszpasterskimi Metropolity Krakowskiego na ostatni etap Wielkiego Postu, 30.03.2020 r., diecezja.pl/aktualnosci/list-ze-wskazaniami-duszpasterskimimetropolity-krakowskiego-na-ostatni-etap-wielkiego-postu/ (dostęp: 28.06.2020).

${ }^{32}$ P. SAWCZUK, List Biskupa Drohiczyńskiego na Wielki Czwartek, 09.04.2020 r., drohiczyńska.pl/aktualności/list-biskupa-drohiczynskiego-na-wielki-czwartek/ (dostęp: 28.06.2020).

${ }^{33}$ J. STEPNOWSKI, List pasterski Biskupa Łomżyńskiego przed 36 PPŁ na Jasna Górę, 28.06.2020 r., diecezja.lomza.pl/kuria/komunikaty-kurii/item/3099-list-pasterski-biskupa-lomzynskiego-przed36-ppl-na-jasna-gore (dostęp: 28.06.2020). 
niewierzących”, dla narodu polskiego - „szczególny moment naszych dziejów” oraz „nadzwyczajnym moment dla świata, Europy, naszej Ojczyzny, wszystkich rodzin i całego Kościoła" ${ }^{34}$.

Z kolei bp Śmigiel z Torunia pisze już w incipicie listu: „Trudny czas epidemii stawia przed naszą Ojczyzną, Kościołem oraz naszą diecezją niespotykane dotąd wyzwania". Następnie padają wyrażenia określające stan epidemii: „czas próby” oraz „trudny egzamin”35. Również w liście, którego autorem jest bp Pindel, pojawiają się podobne wyrażenia: „czas naznaczony trudnym doświadczeniem epidemii koronawirusa”, „nowe doświadczenie i wyzwanie dla diecezji” ${ }^{36}$. Z kolei abp Ryś pisze: „Wszyscy przechodzimy obecnie przez czas próby - jeszcze nie wiemy, jak wielkiej - jak szerokiej (gdy chodzi o zasięg) i jak długotrwałej. Ta próba dotyczy każdego z nas osobiście, ale również dotyczy nas razem jako wspólnoty. Jako Kościół właśnie zdajemy poważny egzamin" ${ }^{\text {"3 }}$. Według bp. Gurdy „trudności w życiu wiarą mogliśmy doświadczyć i my w minionych miesiącach, gdy dotknęły nas obostrzenia spowodowane pandemią koronawirusa" ${ }^{38}$. Abp Polak pisze „o atmosferze niepewności, bezradności i obaw związanych z trwającą epidemią ${ }^{39}$, a abp Dzięga określił czas epidemii jako „dni świadectwa wiary”40.

Jak widać, rozumienie czasu epidemii jako próby łączy się z takimi kategoriami, jak wyzwanie, świadectwo, rekolekcje, egzamin, doświadczenie, które często są wzmacniane przez przymiotnik „trudny”. Jest to więc czas sprawdzianu i weryfikacji postaw religijnych i społecznych, które w nowych okolicznościach wymagają nowych sposobów ich realizacji. Nie bez znaczenia jest też to, że czas ten jest naznaczony niepokojem i trudnościami, a także nowością i nadzwyczajnością, co czyni stające wyzwania jeszcze bardziej niełatwymi.

\footnotetext{
${ }^{34}$ Tamże.

${ }^{35}$ W. ŚMIGIEL, List pasterski bpa Wiesława Śmigla, 25.03.2020 r., diecezja-torun.pl/Artykuly/ View/3566/list-pasterski-bpa-wieslawa-smigla (dostęp: 28.06.2020).

${ }^{36}$ R. PINDEL, List pasterski biskupa bielsko-żywieckiego na zakończenie roku szkolnego 2020, 27.06.2020 r., diecezja.bielsko.pl/aktualnosci/list-biskupa-na-zakonczenie-roku-szkolnego/ (dostęp: 28.06.2020).

${ }^{37} \mathrm{G}$. RYŚ, List do diecezjan dotyczący pandemii koronawirusa.

${ }^{38}$ K. GURDA, List pasterski Biskupa Siedleckiego Kazimierza Gurdy w zwiazku z przygotowaniami do 40. Pieszej Pielgrzymki Podlaskiej na Jasna Górę (2020), 19.06.2020 r., diecezja. siedlce.pl/komunikat/list-biskupa-siedleckiego-z-okazji-40-ppp-na-jasna-gore/ (dostep: 28.06.2020).

${ }^{39}$ W. POLAK, List Prymasa Polski abp. Wojciecha Polaka na III Niedziele Wielkanocna, Niedziele Dobrego Pasterza, 03.05.2020 r., prymaspolski.pl/homilie/list-na-niedziele-dobregopasterza-3-05-2020/ (dostęp: 28.06.2020).

${ }^{40}$ W. PolaK, Stowo pasterskie Księdza Arcybiskupa Metropolity na III Niedzielę Wielkiego Postu, 15.03.2020 r., kuria.pl/aktualnosci/Slowo-pasterskie-Ksiedza-Arcybiskupa-Metropolityna-III-Niedziele-Wielkiego-Postu-15-marca-2020-r_4008 (dostęp: 28.06.2020).
} 


\section{EPIDEMIA JAKO SZANSA}

Jak wiadomo, z sytuacji próby można wyjść dwojako: wzmocnionym i osłabionym. Próba może być szansą. Rozumienie epidemii koronawirusa w kategoriach szansy - choć nie zawsze jest to explicite wyrażone - pojawia się w kilku analizowanych listach pasterskich. Biskup Czaja pisze, że obecna sytuacja ,[...] stwarza możliwość odbudowania tego, co w ostatnich dziesięcioleciach zostało zaniedbane w wielu naszych rodzinach. Mam na myśli troskę o rozwój wiary, jej przeżywanie i praktykowanie we wspólnocie domowników" $"$.

Z kolei bp Pindel zwraca uwagę, że „doświadczenia takie, jak epidemia ujawniają, kim jesteśmy i jaka jest nasza wiara”, „każdy z nas ma [...] swoją opowieść, czego doświadczył i czego się nauczył w tym czasie”. Jednocześnie biskup zachęca swoich diecezjan: „korzystajmy mądrze z doświadczenia pierwszych miesięcy epidemii, aby kolejne miesiące lepiej służyły naszemu wzrostowi”, „uczmy się mądrze odkrywać, co naprawdę jest ważne w naszej wierze, bo przecież w tym czasie kryzysu i pandemii możemy odkrywać, co naprawdę jest ważne, a co może być zmienione"42.

Bp Gurda skupia się na możliwościach, jakie czas epidemii stworzył dla życia rodzinnego: „w tym czasie wiele osób miało szansę powrócić do wspólnej modlitwy w gronie rodziny, rozmów na temat wiary, słuchania i czytania w swoich domach Bożego Słowa, pogłębiania relacji z Chrystusem"43, natomiast abp Polak stwierdził $\mathrm{w}$ bardziej ogólnej konkluzji, że ,[...] czas epidemii w pewien sposób odkrył, kim naprawdę jesteśmy. Pokazał i na nowo uświadomił nam, kto i co faktycznie się w życiu liczy"44.

W sposób najbardziej rozbudowany i kompleksowy o szansach, które stworzył czas pandemii, pisze bp Jeż. Według biskupa tarnowskiego „obecną sytuację możemy starać się wykorzystać pozytywnie". Biskup określa stan epidemii ,jako czas intensywnego wydobywania dobra spod wszelkich nawarstwień zła, które do nas przylega". Zdanie to jest parafrazą zdania wziętego z encykliki Dives in misericordia papieża Jana Pawła II, który pisał: „W swoim właściwym i pełnym kształcie miłosierdzie objawia się jako dowartościowywanie, jako podnoszenie w górę, jako wydobywanie dobra spod

\footnotetext{
${ }^{41}$ A. CzAJA, List Biskupa Opolskiego na V niedziele Wielkiego Postu 2020.

${ }^{42}$ R. PINDEL, List pasterski biskupa bielsko-żywieckiego na zakończenie roku szkolnego 2020.

${ }^{43}$ K. GuRDA, List pasterski Biskupa Siedleckiego Kazimierza Gurdy w zwiazku z przygotowaniami do 40. Pieszej Pielgrzymki Podlaskiej na Jasna Górę (2020).

${ }^{44}$ W. PolaK, List Prymasa Polski abp. Wojciecha Polaka na III Niedzielę Wielkanocna.
} 
wszelkich nawarstwień zła, które jest w świecie i w człowieku"45. Miłosierdzie rozumiane jest więc tutaj bardzo szeroko, nie tylko jako odpuszczenie grzechów, ale jako całościowa relacja Boga do człowieka, który

[...] pragnie nas podnieść ku górze, byśmy zobaczyli szerszy horyzont doczesnego życia i sens naszych codziennych zmagań; który pragnie ukazać nam nowe możliwości, jakie stają się widoczne w Jego boskim świetle. [...] Wobec powszechnego zagrożenia życia ludzkiego możemy na nowo docenić wspaniały dar życia każdego człowieka, od poczęcia do naturalnej śmierci, dostrzegając jego nadprzyrodzoną perspektywę.

Ten model „wydobywania dobra” posłuży biskupowi w opisie różnorakich szans, które daje czas epidemii.

Bp Jeż wskazuje na konkretne „korzyści” płynące z sytuacji, w której Kościół znalazł się z powodu epidemii. Niemożność przystępowania do sakramentów pozwoliła na ponowne dostrzeżenie „,wielkości darów Bożych, do których przyzwyczailiśmy się, gdyż zawsze były one dostępne, niemal na wyciągnięcie ręki”, zapominając przy tym, że jest to „niczym nie zasłużony przez nas przejaw Bożej łaski”. Z kolei brak bezpośredniego kontaktu z wiernymi wzbudził w kapłanach tęsknotę za nimi, a jednocześnie pozwolił „odkryć na nowo nieocenioną wartość wspólnot, zwłaszcza parafialnych”. Z drugiej strony wierni mogą „,...] doświadczyć, czym jest brak dostępu do kapłańskiej posługi i jak może wyglądać sytuacja, gdyby zabrakło kapłanów sprawujących sakramenty święte [...]. Zaistniałe warunki oczyszczają spojrzenie zarówno nam, kapłanom, jak i Wam, świeckim, ucząc nas doceniać to, co jeszcze nadal mamy" - konkluduje ten wątek bp Jeż.

Epidemia jest według niego także czasem ponownego odkrycia wartości Kościoła domowego:

Ograniczony dostęp do kościołów uświadamia nam również, że życie chrześcijańskie nie zamyka się w murach naszych świątyń i nie ogranicza się do celebracji liturgicznych, lecz obejmuje wszystkie wymiary naszego codziennego życia. [...] W obecnych okolicznościach odkrywamy na nowo, iż nasze domy są domowymi Kościołami, w których może rozkwitać życie religijne i w których trzeba chronić najwspanialszy Skarb naszego życia, Jezusa Chrystusa.

W konsekwencji czas epidemii jest także szansą dla życia rodzinnego.

${ }^{45}$ JAN PAWEŁ II, Encyklika „Dives in misericordia”, 1980, nr 6. 
Bieżąca sytuacja - pisze bp Jeż - pomimo wielu obciążeń, daje też możliwość wydobywania pokładów dobra w relacjach małżeńskich i rodzinnych. [...] pojawia się również w tej sytuacji możliwość zbudowania jeszcze silniejszych więzów pomiędzy rodzicami a dziećmi, okazja do dłuższej rozmowy, wzajemnego posłuchania się, odnalezienia się na nowo w darze wspólnie spędzanego czasu. Taka sama możliwość jawi się w perspektywie umacniania więzi i miłości pomiędzy małżonkami.

Ostatnią sferą wspomnianą przez biskupa jest szeroko rozumiana działalność charytatywna:

W tym czasie budowania fizycznego dystansu jeszcze bardziej może się uwydatnić potęga ewangelicznej miłości, która wiedzie nas do podejmowania konkretnych dzieł miłosierdzia ${ }^{46}$.

Analiza dostępnych oficjalnych wypowiedzi ukazuje, że w czasie trwania epidemii biskupi czuli się przede wszystkim rządcami, a nie nauczycielami. Postanowienia, decyzje, nakazy czy dyspensy pojawiały się nie tylko w wydawanych zarządzeniach, dekretach, instrukcjach, lecz także w listach pasterskich, w których element organizacyjny i duszpasterski dominował nad stricte teologicznym. Zresztą listów pasterskich wprost poświęconych problemom związanym z epidemią było ledwie kilka, w kilku innych problem ten pojawiał się jedynie marginalnie. Już sam fakt, że korpus badawczy stanowił tylko 14 jednostek, mówi sam za siebie. Można powiedzieć, że listów pasterskich poświęconych nowej sytuacji - nie tylko społecznej, lecz także kościelnej i religijnej - de facto nie było.

W tych listach, które jednak tego problemu dotknęły, jednoznacznie dominował aspekt pedagogiczny. Biskupi pisali przede wszystkim o tym, jak zareagować na zaistniałą sytuację, jak ją wykorzystać, w jaki sposób może ona posłużyć rozwojowi życia duchowego. Z trzema wyjątkami, biskupi nie czuli się teologami-prorokami, którzy są powołani do interpretacji rzeczywistości i przekazania słowa nadziei w obliczu trudności. A przecież, jak pisze bp Czaja, „Ewangelia rzuca nam światło na ten trudny czas zmagania się z pandemią" ${ }^{47}$. Bo jedynie Ewangelia stanowi właściwy „klucz hermeneutyczny”

\footnotetext{
${ }^{46}$ A. JEŻ, List pasterski Biskupa Tarnowskiego na Niedzielę Bożego Miłosierdzia.

${ }^{47}$ A. Czaja, List Biskupa Opolskiego na V niedzielę Wielkiego Postu 2020 „Jeśli uwierzysz, ujrzysz chwate Boża”.
} 
do odczytywania znaków czasu. Jak zauważa Ryszard Hajduk, „Należy [...] patrzeć na rzeczywistość «oczyma Pana Boga» i tak głosić Ewangelię, aby była ona odpowiedzią na pytania, które stawiają sobie konkretni ludzie"48. Czy należy wnioskować, że biskupi tych pytań nie słyszeli? Czy też nie potrafili na te pytania odpowiedzieć?

Trudno jednoznacznie wyrokować, dlaczego tak się stało, dlaczego powstało w tym czasie tak niewiele listów pasterskich. Być może potencjalni autorzy uznali, że ważniejsza jest właściwa organizacja życia duszpasterskiego i sakramentalnego w nietypowych warunkach niż sama teologiczna interpretacja tych warunków oraz że oczekuje się od nich przede wszystkim regulacji prawnych, które rozwieją pojawiające się wątpliwości natury moralnej. Trzeba jednak pamiętać o właściwym porządku przepowiadania, który został przypomniany przez Konstytucję o Liturgii Świętej, według której najpierw należy przepowiadać misteria fidei, a dopiero potem - zakorzenione $\mathrm{w}$ tych tajemnicach - normae vitae christianae ${ }^{49}$. Być może biskupi uznali, że wystarczy nota Komisji Nauki Wiary, która została opublikowana 31 marca 2020 r. $^{50}$, a była poświęcona kwestiom stricte teologicznym. Dokument ten ukazał się jednak relatywnie późno, gdy panująca epidemia wyzwoliła już wiele dyskusji, koncepcji i teorii pseudoteologicznych.

Dnia 14 marca 2020 r. na internetowym portalu „Więzi” Monika Białkowska opublikowała tekst zatytułowany Odliczanie $w$ drzwiach kościoła. W swoim komentarzu do aktualnej sytuacji pisze m.in.:

[...] ze smutkiem patrzę na to, jak w sytuacji pandemii odnajduje się Kościół instytucjonalny. Jak biskupi, którzy mieli być pasterzami, rozpaczliwie zdają się szukać drogi, która pogodzi pobożność z nauką i która nie narazi ich na krytykę radykalnych środowisk. [...] Kościół w wymiarze instytucjonalnym wydaje kolejne bezosobowe komunikaty [...], które często zaciemniają tylko sytuację. [...] Kościół instytucjonalny nie potrafił zbudować teologii, która łączyłaby głęboką wiarę ze współczesną wiedzą tak, żebyśmy na radzenie sobie $\mathrm{z}$ epidemią mieli odpowiedzi nowsze $\mathrm{i}$ bardziej adekwatne niż te z epoki przed odkryciem wirusów. Moi koledzy teologowie milczą, kiedy biskupi pozostają bezradni wobec braku argumentów, a wierni szerzą apokaliptyczne wizje lub zwykłe herezje ${ }^{51}$.

\footnotetext{
${ }^{48}$ R. HAJduK, Leczyć rany serc złamanych. Przyczynek do kaznodziejstwa terapeutycznego, Wydawnictwo D’EL Art, Kraków 1996, s. 17.

${ }^{49}$ Zob. SoBÓR WATYKAŃSKI II, Konstytucja o Liturgii Świętej „, Sacrosanctum concilium”, nr 52.

${ }^{50}$ Jezus żyje i chce, abyś żyt. Nota Komisji Nauki Wiary Konferencji Episkopatu Polski w związku z pandemią koronawirusa, 31.03.2020 r.

${ }^{51}$ M. BiaŁKowsKA, Odliczanie w drzwiach Kościoła, 14.03.2020 r., wiez.com.pl/2020/03/14/ odliczanie-w-drzwiach-kosciola/ (dostęp: 30.06.2020).
} 
Niestety, przeprowadzona analiza listów pasterskich czasu epidemii, zarówno tych wydawanych w pierwszych jej dniach, jak i w końcowej fazie, zdaje się potwierdzać gorzką konstatację redaktorki „Przewodnika Katolickiego". Niewielu bowiem biskupów podjęło próbę stawienia czoła nowemu teologicznemu i pastoralnemu wyzwaniu. A przecież to przede wszystkim dzięki nauczaniu pasterskiemu biskupów słuchacz słowa powinien „doświadczyć uzdrawiającej mocy Ewangelii, która pomoże mu znaleźć odpowiedź na jego konkretne pytania w jego aktualnej sytuacji życiowej $\mathrm{i}$ w ten sposób pozwoli mu uzyskać poczucie sensu istnienia" ${ }^{92}$.

\section{BIBLIOGRAFIA}

BiAŁKowsKa M., Odliczanie w drzwiach Kościoła, 14.03.2020 r., wiez.com.pl/2020/03/14/odliczaniew-drzwiach-kosciola/ (dostęp: 30.06.2020).

CZAJA A., List Biskupa Opolskiego na V niedzielę Wielkiego Postu 2020 „Jeśli uwierzysz, ujrzysz chwałę Bożą", 29.03.2020 r., www.diecezja.opole.pl/index.php/biskupi-infor macje/bp-andrzejczaja/2525-list-biskupa-opolskiego-na-v-niedziele-wielkiego-postu-2020 (dostęp: 28.06.2020).

Dokowicz L., BodasiŃski M., Wezwanie do pokuty, 9.03 .2020 r., www.youtube.com/watch ?v=zNsLJr0dqOk (dostęp: 30.06.2020).

Drews K., Posługa biskupa we współczesnym Kościele, „Studia Gdańskie” 25(2009), s. 35-49.

DzIĘGA A., Słowo pasterskie Księdza Arcybiskupa Metropolity na III Niedzielę Wielkiego Postu, 15.03.2020 r., kuria.pl/aktualnosci/Slowo-pasterskie-Ksiedza-ArcybiskupaMetropolity-na-IIINiedziele-Wielkiego-Postu-15-marca-2020-r_4008 (dostęp: 28.06.2020).

GURDA K., List pasterski Biskupa Siedleckiego Kazimierza Gurdy w związku z przygotowaniami do 40. Pieszej Pielgrzymki Podlaskiej na Jasną Górę (2020), 19.06.2020 r., diecezja.siedlce.pl/ komunikat/list-biskupa-siedleckiego-z-okazji-40-ppp-na-jasna-gore/ (dostęp: 28.06.2020).

HAJDUK R., Leczyć rany serc złamanych. Przyczynek do kaznodziejstwa terapeutycznego, Wydawnictwo D’EL Art, Kraków 1996.

JAN PAWE⿺ II, Adhortacja posynodalna „Pastores gregis”, Watykan 2003.

JAN PAWEŁ II, Encyklika „Dives in Misericordia”, Watykan 1980.

Jezus żyje i chce, abyś żył. Nota Komisji Nauki Wiary Konferencji Episkopatu Polski w związku $\mathrm{z}$ pandemią koronawirusa, 31.03.2020 $\mathrm{r}$.

JEŻ A., List pasterski Biskupa Tarnowskiego na Niedzielę Bożego Miłosierdzia, 19.04.2020 r., diecezja. tarnow.pl/images/do_pobrania/List_NMB_2020.pdf (dostęp: 28.06.2020).

JĘDRASZEWSKi M., List ze wskazaniami duszpasterskimi Metropolity Krakowskiego na ostatni etap Wielkiego Postu, 30.03.2020 r., diecezja.pl/aktualnosci/list-ze-wskazania mi-duszpasterskimimetropolity-krakowskiego-na-ostatni-etap-wielkiego-postu/ (dostęp: 28.06.2020).

\footnotetext{
${ }^{52}$ R. HAJDUK, Leczyć rany, s. 25.
} 
KASZAK G., List biskupa Grzegorza Kaszaka w związku z epidemią, 15.03 .2020 r., diecezja. sosnowiec.pl/news/list-biskupa-w-zwiazku-z-epidemia-3881 (dostęp: 28.06.2020).

KongregacJa DS. Biskupów, Dyrektorium o pasterskiej posłudze biskupów „Apostolorum succesores”, w: Ustrój hierarchiczny Kościoła. Wybór źródeł, red. W. Kacprzyk, M. Sitarz, Wydawnictwo KUL, Lublin 2006, s. 558-559.

KONGREGACJA DS. BISKUPÓw, Instrukcja na temat pasterskiej posługi biskupów „Ecclesiae imago”, w: Ustrój hierarchiczny Kościoła. Wybór źródeł, red. W. Kacprzyk, M. Sitarz, Wydawnictwo KUL, Lublin 2006, s. 403-516.

KUPNY J., List Metropolity Wrocławskiego ks. abp. Józefa Kupnego do wiernych Archidiecezji Wrocławskiej, 19.03.2020 r., www.archidiecezja.wroc.pl/index.php?option=com_content\&view=article \&id=2814:kochanimieszkacydolnegolska\&catid=62:aktualnoci\&Itemid=205 (dostęp: 28.06 .2020$)$.

PINDEL R., List pasterski biskupa bielsko-żywieckiego na zakończenie roku szkolnego 2020, 27.06.2020 r., diecezja.bielsko.pl/aktualnosci/list-biskupa-na-zakonczenie-roku-szkolnego/ (dostęp: 28.06.2020).

POLAK W., Jesteśmy w rękach Boga, 17.03.2020 r., www.archidiecezja.pl/aktualnosci/archiwum/ 2020/marzec/jestesmy_w_rekach_boga_html (dostęp: 30.06.2020).

PolaK W., List Prymasa Polski abp. Wojciecha Polaka na III Niedzielę Wielkanocną, Niedzielę Dobrego Pasterza, 03.05.2020 r., prymaspolski.pl/homilie/list-na-niedziele-dobrego-pasterza-305-2020/ (dostęp: 28.06.2020).

RYŚ G., List do diecezjan dotyczący pandemii koronawirusa, 14.03.2020 r., www.archidiecezja. lodz.pl/film/abp-rys-list-do-diecezjan-dot-pandemii-koronawirusa-lodz-2020/ (dostęp: 28.06.2020).

SAWA P., Projekt Ocalenie - czyli jakie błędy popełniają Bodasiński i Dokowicz, deon.pl/kosciol/ komentarze/jakie-bledy-popelniaja-bodasinski-idokowicz,834302 (dostęp: 30.06. 2020).

SAWCZuK P., List Biskupa Drohiczyńskiego na Wielki Czwartek, 09.04.2020 r., drohiczyńska.pl/ aktualności/list-biskupa-drohiczynskiego-na-wielki-czwartek/ (dostęp: 28.06.2020).

SKowroneK K., Między sacrum a profanum. Studium językoznawcze listów pasterskich Konferencji Episkopatu Polski (1945-2005), Wydawnictwo Lexis, Kraków 2006.

SOBÓR WATYKAŃSKi II, Dekret o pasterskich zadaniach biskupów „Christus Dominus”, w: Sobór Watykański II, Konstytucje. Dekrety. Deklaracje, Pallottinum, Poznań 2012, s. 48-78.

SobÓR WATYKAŃSKi II, Konstytucja dogmatyczna o Kościele „Lumen gentium”, w: Sobór Watykański II, Konstytucje. Dekrety. Deklaracje, Pallottinum, Poznań 2012, s. 104-166.

SOBÓR WATYKAŃSKI II, Konstytucja duszpasterska o Kościele w świecie współczesnym „Gaudium et spes”, w: Sobór Watykański II, Konstytucje. Dekrety. Deklaracje, Pallottinum, Poznań 2012, s. 526-606.

SOBÓR WATYKAŃSKI II, Konstytucja o świętej liturgii „Sacrosanctum concilium”, w: Sobór Watykański II, Konstytucje. Dekrety. Deklaracje, Pallottinum, Poznań 2012, s. 48-78.

STEPNOWSKI J., List pasterski Biskupa Łomżyńskiego przed 36 PPŁ na Jasną Górę, 28.06.2020 r., diecezja.lomza.pl/kuria/komunikaty-kurii/item/3099-list-pasterski-biskupa-lomzynskiego-przed36-ppl-na-jasna-gore (dostęp: 28.06.2020). 
STEPNOWSKI J., List pasterski Biskupa Łomżyńskiego w związku z sytuacją panującej epidemii, 13.03.2020 r., diecezja.lomza.pl/kuria/komunikaty-kurii/item/2968-list-pasterskibiskupa-lomzynskiego-w-zwiazku-z-sytuacja-panujacej-epidemii (dostęp: 28.06.2020).

ŚMIGIEL W., List pasterski bpa Wiesława Śmigla, 25.03.2020 r., diecezja-torun.pl/Artykuly/View/ 3566/list-pasterski-bpa-wieslawa-smigla (dostęp: 28.06.2020).

WOJTAK M., List pasterski - pragmatyczny aspekt wzorca gatunkowego, w: Znak językowy w pejzaży semiotycznym. Księga pamiątkowa ku czci Profesora Józefa Wierzchowskiego, red. J. Gardzińska, A. Maciejewska, Wydawnictwo Akademii Podlaskiej, Siedlce 2003, s. 185-198.

WROCEŃSKi J., Obowiązki pasterskie biskupa diecezjalnego, „Prawo Kanoniczne” 51(2008), nr 3-4, s. $119-145$.

ŻyNEL A., Znaki czasu, „Znak” 1969, nr 12, s. 1578-1593.

\section{LISTY, KTÓRYCH NIE BYŁO. TEOLOGICZNA INTERPRETACJA CZASU EPIDEMII W LISTACH PASTERSKICH BISKUPÓW POLSKICH}

\section{Streszczenie}

Dokumenty Kościoła posoborowego jednoznacznie stwierdzają, że głoszenie słowa Bożego wysuwa się na czoło pasterskich zadań biskupów. Oprócz głoszenia prawd wiary istotnym obowiązkiem pozostaje interpretacja rzeczywistości doczesnej w świetle Ewangelii. Obok homilii podstawową formą przepowiadania jest list pasterski, o którym dokumenty poświęcone posłudze biskupów mówią, że powinny być wydawane w sytuacjach szczególnych okoliczności, w jakich znajduje się Kościół. Jak się wydaje, taką okolicznością jest epidemia koronawirusa powodująca chorobę określaną jako COVID-19. Kwerenda przeprowadzona na oficjalnych stronach internetowych diecezji pokazała, że w okresie od marca do końca czerwca 2020 r. na 41 biskupów diecezjalnych obrządku łacińskiego w Polsce tylko 12 wydało listy poświęcone całkowicie lub częściowo kwestiom związanym z epidemią. Tylko w trzech listach pojawily się próby teologicznych interpretacji za pośrednictwem biblijnych modeli. Także jedynie trzech biskupów odniosło się do kwestii epidemii jako zła nadprzyrodzonego. W pozostałych listach dominował aspekt pedagogiczny. Autorzy listów pisali o epidemii jako czasie próby, okazji do nawrócenia i pokuty. Biskupi nie wykorzystali szansy na pogłębioną refleksję na temat epidemii sub specie aeternitatis.

Słowa kluczowe: list pasterski; biskup; epidemia koronawirusa; zło. 